\title{
Resource Based Theory of Accelerator Programme
}

Matshediso Elizabeth Mohapeloa ( $\nabla$ t.mohapeloa@ru.ac.za)

Rhodes University Faculty of Commerce https://orcid.org/0000-0002-9137-2912

Mmankitseng Lerato Mametsi

Rhodes University

\section{Research}

Keywords: Resource based theory, Accelerator programme, Start-ups

Posted Date: July 8th, 2020

DOI: https://doi.org/10.21203/rs.3.rs-40107/v1

License: () (1) This work is licensed under a Creative Commons Attribution 4.0 International License. Read Full License 


\section{Abstract}

Accelerators help accelerate startups through formal education and mentorship connections during intensive, temporally-compressed programmes for a period of three -six months. This paper investigate how Resource Based Theory (RBT) posits accelerators for sustained competitive advantage of startups. Our research question was to determine the value (in terms of resources offered) that accelerators bring to benefit startups that have been through the acceleration programmes. Our focus was to uncover what value gets created by accelerator programme and how.

Through this qualitative study we selected a multiple case study method of 5 accelerator programmes in South Africa. For analysis we linked the RBT (tangible and intangible resources) for each accelerator's entrepreneurial ecosystem, to determine if the phenomenon of the burgeoning accelerator industry can be better understood. Document reviews were explored to determine intended impact that sustain success for startup (technology) companies.

Findings revealed that accelerators ensure that fewer startups fail and more SME's become sustainable into the future. Secondly accelerators help startup companies define and build their initial products. Thirdly upscale is achieved through, identification of promising customer segments. Finally mentorship and accelerator process enhanced and securing resources is strengthening necessary resources available to startups.

\section{Introduction}

Accelerator programmes, have been supporting startups to move to the next level of growth, development and to replicate yielded success from original accelerator programme. The work done by Y-Combinator through available resources has made startup such as Airbnb and Dropbox to grow exponentially. Accelerators accelerate startups by providing startups with formal education and mentorship (Yitshaki and Drori, 2018), enhance connections during intensive, temporally-compressed programmes that usually last for three months (Hallen, et al. 2014).This paper investigate how Resource Based Theory (RBT) lens posits accelerators to sustained competitive advantage for startups. For this we looked at the utilisation accelerator's resources (including physical, human and organisational) in a manner that is effective and efficient, both internally and externally for startups. Our research question was to determine the value (in terms of resources offered) that accelerators bring to benefit startups that have been through the acceleration programmes. Our focus was to uncover what value gets created by accelerator programme and how.

The accelerator industry focus on small emerging companies and supports startups that have the potential of becoming national or global players. They use traditional model of deploying resources and capabilities as espoused by Grant (1991). For accelerators, taking a percentage from startups equity of about $5 \%-6 \%$ is a viable financial model for sustainability although this is limited to those participating in bootcamp ventures (Radojevich-Kelley and Hoffman, 2012). However, about $67.2 \%$ is from corporate funding whilst $65.5 \%$ is due to for-profit ventures (Global Accelerator Report, 2016). Enterprises that do not access to all the resources and capabilities required to gain competitive advantage that produce superior returns form strategic alliances to make up for the lacking of these resources and capabilities. Enterprises are required to own at least $50 \%$ of their own resources to be successful (Bretherton and Chaston, 2004).

0466223476

\section{Review Of Literature}

Grant (1991)'s resources based theory focus on the inputs into the production process and profitability of a company by exploring resources and capabilities of a company for competitive advantage. It argues that possession of strategic resources creates an excellent opportunity for competitive advantage against rivals. The Resource Based Theory (RBT) offers an approach to analysing accelerator programmes by looking at its theoretical frameworks. However, Barney (1991) looked at firm resources as physical capital (technology, location, equipment and raw material), human capital (training, experience, judgement, intelligence, relationships and insight) and organisational capital (structure, planning, controlling, coordination of systems, and internal relationships) that a firm uses to implement its strategies to achieve competitive advantage in the market (Barney, 1991). Resources are used as internal capabilities that mitigate constraints (Koponen, 2012; Smith \& Stevens, 2010) in terms of human capital, financial capital, infrastructure and technology. This acknowledges contribution of resources on capabilities and strategic imperatives that enhance competitive advantage (Yunus et al. 2010; Alt \& Zimmerman, 2014; Ostenwalder et al., 2005; Mahadevan, 2000, and Schweizer, 2005), as they emphasise how these help achieve sustainable competitive advantage.

\section{Core Attributes and Characters of RBT}

Competitive advantage breeds when a firm portrays unique resources according to the resource-based perspective (Conner and Prahalad, 1996; Barney 1991). Barney (1991)'s attributes for competitive advantages includes heterogeneity and immobility of resources. These are crucial for competitive advantage and value creating strategies that are not being used by other competitors in the market (Barney 1991). Heterogeneous provides competitive advantage whilst immobile ensures uniqueness and non -transferability. This mean the value of tangible and non-tangible resources must be linked to rareness, imperfectly imitable and non-substitutable (Barney, 1991), that provide an organisation with a competitive advantage that is effective and efficient, both internally and externally to outperform their competitors in the market (Hitt, et al., 2015). Thus effective strategies to improve efficiency and effectiveness help exploit opportunities and neutralise threats in the external environment are essential. Rare resources are few or no other organisations have the same resource, have a unique historical condition, are casually ambiguous, and socially complex, making them imperfectly imitable to be duplicated. Resources are nonsubstitutable when there are no strategically similar substitutes that exist.

Grant (1991) identified characteristics of resources and capabilities as durability, transferability, transparency and replicability. Sustained competitive advantage cannot be sustained as information symmetry which corrects market is available to the rest of the market (Grant 1991). This means that the durability of a company's resources and capability gets eroded over time but should be maintained for competitive advantage through maintaining and 
renewed culture and necessary socialisation of new employees. Lack of transparency in relation to how the company maintain, implementing its strategy for competitive advantage. Transferability is the ability to transfer unique resources and capabilities to a particular company due to location, information asymmetry, complex combination of resources and capabilities. Thus the ability to duplicate capabilities can be difficult due to the combination of these (Grant, 1991). Resource Based Theory to entrepreneurship, they include the cognitive ability of entrepreneurs as an additional human resource that enhances sustained competitive advantage and creates wealth for the company (Alvarez and Busenitz, 2001). Radojevich-Kelley and Hoffman (2012) applied the resources based theory to the services that accelerators provide and looked at the kinds of resources provided to startups to determine the success post the acceleration process. Findings highlighted the success of startup results from the resources the accelerators provide (Radojevich-Kelley and Hoffman, 2012).

\section{Contributiond of RBT for Entrepreneurs and Accelerators}

The resource based theory (RBT) has been applied to entrepreneurship to identify and explain how nascent companies can outperform others (Alvarez and Busenitz, 2001) yet, it was also used on services that accelerators provide (Radojevich-Kelley and Hoffman, 2012). Bretherton and Chaston (2004) applied the resource-based approached to small and medium-sized enterprises (SMMEs). Entrepreneurship is viewed as wealth creation that recognise the advantage taking advantage of environmental opportunities in the environment by developing new processes, new products or developing new markets (Ireland, Hitt and Sirmon ,2003). Managing resources strategically (Adner \& Helfat, 2003; Ireland, Sirmon \& Hitt, 2003) will enhance the identification and taking advantage of opportunities in the external environment for wealth creation (Ireland, et al 2003). Ireland, et al (2003) highlighted critical resources required for strategic entrepreneurship as financial (monetary), human (expertise, knowledge and skills) and social capital (value created through relationship fostered between internal and external stakeholders).

Isenberg (2014), argues that fostering entrepreneurship requires the nurturing of an entrepreneurship ecosystem whilst Ireland et al., (2003) focused on structures (acquiring, accumulating, and divesting), bundle resources (to create rare and valuable capabilities), and how these leverage capabilities (achieved through experienced management) to take advantage of the opportunities present in the external environment can position the company to have a competitive advantage and create wealth for its stakeholders (Ireland, et al. 2003, p.977). This ecosystem focus on leadership and government policy, financial capital, culture (including success stories and societal norm), support services (including infrastructure and other services), human capital, and markets (including customers and networks) something that accelerator programmes try to replicate when nurturing entrepreneurship to startups. However, a study done in South Africa highlighted $52 \%$ of the founders, identified access to funding as the biggest challenge whilst, $63 \%$ of founders reported having used self-funding or friends and family donations and loans for the first round of funding their business (Ventureburn, 2017). The creation of accelerators were largely created to give back to the startup communities by offering the kind of support presumed to be a gap for entrepreneurs (Radojevich-Kelley and Hoffman, 2012). On growth strategies companies rely on dynamic abilities(Li, and Rama, 2015) as the company's capabilities (Brown and Mawson, 2016) a critique of looking at RBT as it does not only focus on tangible resources but also on tacit knowledge as a resource Brown and Mawson, 2016).

The biggest challenges faced by startups can be mitigated through accelerator programmes to include: funding (Fehder, and Hochberg, 2018), understanding target market, marketing expertise, reaching customers, and lacking experience in their proposed business (Radojevich-Kelley and Hoffman, 2012). According to Winston Smith et al. (2013) startups backed by an accelerator programme receive their first round of follow-up financing significantly sooner than startups that did not participate in acceleration programmes. Strategic entrepreneurship looks at gain and maintain a competitive advantage thus identifying opportunities in the external environment and exploit these opportunities through the appropriate deployment of valuable, rare, imperfectly imitable and nonsubstitutable resources becomes essential (Ireland, et al. 2003). Entrepreneurial cognition allows entrepreneurs to develop solutions by taking on the opportunity identified in the environment (Alvarez and Busenitz, 2001).

Peteraf (1993) proposes ex-post limits to competition (forces that limit competition once a competitive advantage is attained) to be in place to attain sustained competitive advantage for imperfect imitability and imperfect substitutable (Peteraf, 1993). However, cognitive differences, strategic complementarity, causal ambiguity, uncertainty, and information asymmetries have allowed entrepreneurs to sustain competitive advantage (Alvarez and Busenitz, 2001). Cognitive differences enhances high performing companies (Alvarez and Busenitz, 2001; Westhead \& Wright, 1998; Rosa \& Scott, 1999). Strategic complementarity leads to the creation of new invention that complement or create solution. (Alvarez and Busenitz 2001) to highlight Schumpeter (1934)'s creative destruction, (Ormiston \& Seymour 2011, Hamel 2000) which suggests that "new combinations of resources leads to new ways of competing (Alvarez and Busenitz, 2001). Causal ambiguity looks at vagueness of the things that bring about efficiency in a business which may be different to how efficiency is created in the next business differences (Alvarez and Busenitz, 2001 p.766).

\section{Critiques of Resource Based Theory and Accelerator Programmes}

Critique of the accelerator programmes as highlighted by Brown and Mawson (2016) looked at the targeted support that high growth companies receive from accelerator type institutions and highlighted the following shortcomings of accelerator programmes: That the accelerator programmes are skewed to working with only certain sectors and high growth firms that are not in that sector are overlooked and do not receive the required assistance. Unintended consequences emerge such as the change in the entrepreneurial behaviour of the company as a result of intense levels of support given by the accelerator programme. The authors also note that accelerated companies tend to underperform non-accelerated companies because those companies that grew over time had the opportunity to adjust and put systems in place to deal with the challenges that come with the growth. (Brown and Mawson, 2016).

Critique of Resource Based Theory focused on the flawed theoretical assumptions of RBT underpin the support of the accelerator programmes instead it should be built around more relevant theories around entrepreneurship such as dynamic capability theory (Brown and Mawson, 2016). Kraaijenbrink, Spender and Groen et al., (2010) looked at resource based view and how these impede on the RBT the absence of managerial implications, the implications on infinite regression, the limited applicability, unachievable sustained competitive advantage, the too indeterminate value of resources to provide a useful theory, the resource-based view is not a theory about the firm, valuable, rare, imitable, non-transferable resources are not necessary sufficient to achieve sustained 
competitive advantage and the definition of a resource which is not workable. However in the context of accelerator identifying the necessary resources required to attain competitive advantage is a first step in determining their value.

To identify the necessary resources required to attain competitive advantage resource-based theorists have highlighted resources such as strategic planning (Michalisin et al 1997; Fahy and Smithee, 1999; Makadok, 2001) management skills (Castanis and Helft 1991), tacit knowledge (Polanyi, 1962, 1966), capital, employment of skilled personnel (Wernerfelt, 1984) including assets and resources owned by companies (Barney 1991; Grant 1991; and Peteraf 1993) to aid performance. Skill set tends to influence, the performance of the business (Lerner and Almor, 2002). This helps towards the first step in determining value (Kraaijenbrink, et al. 2010) whilst resource based view describes how business owners build their businesses from the resources and capabilities that they currently possess or can acquire (Dollinger, 1999; Saffu and Manu 2005)). tends to complement RBT whilst there is need to further refine resource types beyond static ones (physical, human and organisation) but to include dynamic; tangible, intangible; financial, human, technological; deployed, in reserve; perishable, non-perishable; and those between types of resource ownership (Kraaijenbrink, et al. 2010).

\section{Methodology}

A multiple case study method as an exploratory approach was selected (Baskarad, 2014, Yin 2009). The researchers used qualitative approach to explore multiple cases of accelerator programmes in South Africa to allow the creation of subjective meaning amongst participants as o tell their own story (Baxter and Jack, 2008), thus allowing for the analysis of a phenomenon within each company and across the industry. Our research design used Yin (2009) steps of exploring the theory (RBT), where we selected cases by reviewing accelerator programmes operating in South Africa then write-up each individual case report developing a data collection protocol to guide the systematic process of analysing each case before the selection of the next information gathered also enhanced the quality of data.

Accelerator programmes are mainly based in the Western Cape or Gauteng. The Western Cape accounted for $56 \%$ of all venture capital funding and Gauteng accounted for $32 \%$ (Southern African Venture Capital and Private Equity Association-SAVCA, 2017). Thus selected accelerator programmes had headquartered in Gauteng or the Western Cape, and have been in operation since January 2015 (or before), with publicly available and verifiable information.

Document review from publically available documents for each of the accelerators was the triangulated increase the wealth and quality of data to modify theory and develop policy implications. From a population of twenty (20) South African accelerators as purposeful sampling of five (5) was used in for the selection of information-rich cases and to reflect the purpose and aim (Mason, 2010) without compromising credibility and transferability (Guba \& Lincoln, 1981; Mason, 2010). This an acceptable variable for phenomenology from five to 25 (Creswell, 1998), while Morse (1994) suggests at least six as it represents $25 \%$ of the population (Grinnell and Williams, 1990; de Vos et al. 2011).

\section{Results And Findings}

We first present the profile that gives brief description of who and what the accelerator do, where they are located, their focus areas. The accelerator programmes works with startup at different developmental stages where four focused on technology startups either through software or hardware, whilst one focuses on social impact regardless technology use or not. The accelerator programmes work with startups, from ideation to high-growth.

Table 1

Snapshot profile and accelerator outcomes

\begin{tabular}{|c|c|c|c|c|}
\hline Accelerator & Focus area & $\begin{array}{l}\text { Primary } \\
\text { programme } \\
\text { delivery areas }\end{array}$ & Startup VIndividual YProduct & $\begin{array}{l}\text { Stage of } \\
\text { development }\end{array}$ \\
\hline Grindstone & Post-revenue high-growth technology enabled SMEs & Cape Town & $\begin{array}{l}\text { Founders, CEO, senior } \\
\text { manager, managing } \\
\text { director, partner }\end{array}$ & $\begin{array}{l}\text { Post-revenue high- } \\
\text { growth stage }\end{array}$ \\
\hline LaunchLab & $\begin{array}{l}\text { Clean tech, block chain, big data, artificial intelligence, agri tech } \\
\text { (veggie tech), space tech, smart manufacturing and smart seeding }\end{array}$ & Stellenbosch & Startup & Ideation \\
\hline MLab & $\begin{array}{l}\text { Information and Communications Technology (ICT) startups, that } \\
\text { cuts across industry with innovative digital solution app, mobile } \\
\text { solutions, Unstructured Supplementary Service Data (ussd) and } \\
\text { wearables }\end{array}$ & $\begin{array}{l}\text { Pretoria, } \\
\text { Johannesburg, } \\
\text { Cape Town }\end{array}$ & Product & Ideation \\
\hline Spark & $\begin{array}{l}\text { Not focusing on a particular industry, as long as you are a startup } \\
\text { has a social impact focus }\end{array}$ & Johannesburg & Startup & $\begin{array}{l}\text { Entrepreneurs in } \\
\text { early stages of a } \\
\text { great idea, startup } \\
\text { has been } \\
\text { launched and has } \\
\text { its first customer. }\end{array}$ \\
\hline Sw7 & Technology \& high growth businesses & $\begin{array}{l}\text { Johannesburg } \\
\text { and Cape } \\
\text { Town }\end{array}$ & Founders & High growth stage \\
\hline
\end{tabular}

\section{Resources}

Various physical resources are provided allow progress in product/service to gain an advantage in the market. Categories such as location, working space were viewed as categories of physical resource. Financing for product development was key for all accelerators however aspects such as location seems to be 
influenced by proximity to the university's resources (Launchlab, next to Stellenbosch) and the entrepreneurial cultures, a town that embrace entrepreneurial ecosystem enhance creative spaces a such as Innovation Hub (MLab in Pretoria).

Table 2: Resources (Physical, Human \& Organisational)

\begin{tabular}{|c|c|c|c|c|c|}
\hline Physical resources & Grindstone & LaunchLab & MLab & Spark & Sw7 \\
\hline Location & $\hat{\mathrm{u}}$ & $\ddot{\mathrm{u}}$ & $\ddot{\mathrm{u}}$ & $\hat{\mathrm{u}}$ & $\hat{\mathrm{u}}$ \\
\hline Office space with meeting rooms & $\hat{\mathrm{u}}$ & $\ddot{\mathrm{u}}$ & $\ddot{\mathrm{u}}$ & $\hat{\mathrm{u}}$ & $\hat{\mathrm{u}}$ \\
\hline Equipment & $\hat{\mathrm{u}}$ & $\hat{\mathrm{u}}$ & $\ddot{\mathrm{u}}$ & $\hat{\mathrm{u}}$ & $\hat{\mathrm{u}}$ \\
\hline Software & $\hat{\mathrm{u}}$ & $\hat{\mathrm{u}}$ & $\ddot{\mathrm{u}}$ & $\hat{\mathrm{u}}$ & $\hat{\mathrm{u}}$ \\
\hline Internet & $\hat{\mathrm{u}}$ & $\ddot{\mathrm{u}}$ & $\ddot{\mathrm{u}}$ & $\hat{\mathrm{u}}$ & $\hat{\mathrm{u}}$ \\
\hline Financing to develop product during programme & $\ddot{\mathrm{u}}$ & $\ddot{\mathrm{u}}$ & $\ddot{\mathrm{u}}$ & $\ddot{\mathrm{u}}$ & $\ddot{\mathrm{u}}$ \\
\hline Subsidies or bursaries & $\ddot{\mathrm{u}}$ & $\hat{\mathrm{u}}$ & $\hat{\mathrm{u}}$ & $\hat{\mathrm{u}}$ & $\ddot{\mathrm{u}}$ \\
\hline Travel & $\hat{\mathrm{u}}$ & $\hat{\mathrm{u}}$ & $\ddot{\mathrm{u}}$ & $\hat{\mathrm{u}}$ & $\hat{\mathrm{u}}$ \\
\hline Human resources & Grindstone & LaunchLab & MLab & Spark & Sw7 \\
\hline Experienced mentors at accelerator & $\ddot{\mathrm{u}}$ & $\ddot{\mathrm{u}}$ & $\ddot{\mathrm{u}}$ & $\ddot{\mathrm{u}}$ & $\ddot{\mathrm{u}}$ \\
\hline Independent experienced mentors & $\ddot{\mathrm{u}}$ & $\ddot{\mathrm{u}}$ & $\ddot{\mathrm{u}}$ & $\ddot{\mathrm{u}}$ & $\ddot{\mathrm{u}}$ \\
\hline Ecosystem networking and relationship building & $\ddot{\mathrm{u}}$ & $\ddot{\mathrm{u}}$ & $\ddot{\mathrm{u}}$ & $\ddot{\mathrm{u}}$ & $\ddot{\mathrm{u}}$ \\
\hline Peer learning and support & $\ddot{\mathrm{u}}$ & $\ddot{\mathrm{u}}$ & $\ddot{\mathrm{u}}$ & $\ddot{\mathrm{u}}$ & $\ddot{\mathrm{u}}$ \\
\hline Psychometric test & $\hat{\mathrm{u}}$ & $\hat{\mathrm{u}}$ & $\hat{\mathrm{u}}$ & $\hat{\mathrm{u}}$ & $\ddot{\mathrm{u}}$ \\
\hline Classroom based training & $\ddot{\mathrm{u}}$ & $\ddot{\mathrm{u}}$ & $\ddot{\mathrm{u}}$ & $\ddot{\mathrm{u}}$ & $\ddot{\mathrm{u}}$ \\
\hline Organisational resources & Grindstone & LaunchLab & MLab & Spark & Sw7 \\
\hline Structure & $\ddot{\mathrm{u}}$ & $\hat{\mathrm{u}}$ & $\hat{\mathrm{u}}$ & $\hat{\mathrm{u}}$ & $\ddot{\mathrm{u}}$ \\
\hline Planning & $\ddot{\mathrm{u}}$ & $\hat{\mathrm{u}}$ & $\hat{\mathrm{u}}$ & $\hat{\mathrm{u}}$ & $\ddot{\mathrm{u}}$ \\
\hline Controlling & $\ddot{\mathrm{u}}$ & $\hat{\mathrm{u}}$ & $\hat{\mathrm{u}}$ & $\hat{\mathrm{u}}$ & $\ddot{\mathrm{u}}$ \\
\hline Systems & $\ddot{\mathrm{u}}$ & $\hat{\mathrm{u}}$ & $\hat{\mathrm{u}}$ & $\hat{\mathrm{u}}$ & $\ddot{\mathrm{u}}$ \\
\hline
\end{tabular}

When it comes to Human Capital as a Resources it could be stated that accelerator programmes offer mentorship, peer learning to supplement classroombased training. These are provided in a more formal learning by experienced entrepreneurs and corporate partners. However psychometric test is only part of one (Sw7) responded. But when looking at organisational resources aspects such as structures, planning tools, controlling tools, coordination of systems, and internal relationships that a firm uses to implement its strategies (Barney, 1991). Thus Accelerator programmes focusing on startups in the ideation stage of their development do not provide organisational resources. However, their focus remains on developing the product or service of the startup (LaunchLab, Mlab and Spark). Grindstone and Sw7 focus on later stages provide resources to enable startup founders and managers to better manage their organisation to prepare for high growth or to put systems in place to cope with the anticipated growth.

\section{Success Factors}

Determining the success that accelerator programmes have on startups was also difficult as measures were viewed in both quantified and qualified measurement. However, some had difficulty linking success with the number of beneficiaries that completed the programme in relation to those that attended a portion of the programme and through an adjacent programme such as an incubator. Accelerators, own definition of success looked at job creation, access to further funding and revenue generation as metrics that acceleration programmes used to measure their success or impact.

At ideation success is viewed as being able to take the idea of the startup and have a proof of concept, a minimum viable product or a prototype (MLab and LaunchLab). Being able to take the product to market, test it and incorporate feedback from the market into the next iteration of the product, was a measure they used for success. Spark, focused on startups that already have their first customer, thus define success as the increased impact such moved from impacting 10 customers (people in society) to 100, as success. LaunchLab claimed to have achieved $83 \%$ success rate with $83 \%$ of their startups. Sw7 claims to have worked with over 200 startups from early to mature stage and measure their success according to the successful execution of strategy, increased access to market, effective deal structuring, being able to scale the business and gaining access to funding (Sw7 SlideShare, 2017).

\section{Funding and Financial Resources}

The accelerators that focus on the high growth phase startups and entrepreneurs put emphasis on financial metrics. Spark reports that it has supported hundreds of entrepreneurs and $90 \%$ of these entrepreneurs have at least doubled their revenue and impact (Ventureburn, 2018). MLab leverage finance of 35$40 \%$ of the startups that had gone through the programme thus securing between R100k to R9 million from funders to take startup product or service further. Through accelerator networks access to foreign markets and increase in customer access occurs. For instance one startup had achieved 70000 users. LaunchLab focused on corporate clients and partnerships to provide a service to the corporate client, products receiving international exposure, with new clients or foreign direct investment, acquisition by a bigger venture and investment into the company by investors in return for equity. Grindstone financial metrics looks at increase revenue (monetary and percentage), new jobs created, increased efficiencies (as determined by revenue/ employee) and increased business fundamentals (Knife Capital, 2018). These are based on three of their major accelerator programmes (Grindstone 1, 2 \& 3 ) to determine success (Knife Capital, 2018).

\section{Discussion}


This research investigated accelerator programmes in South Africa using the Resource Based Theory by focusing on resources provided by accelerators. Participants separated these into physical, human and organisational resources. The resource accelerator programmes deliver to the startups translates into valuable capital that the startups can use to gain a competitive advantage in their chosen markets. This is supported by Barney's(1991) definition of firms' resources required to attain sustained competitive advantage in the market as physical capital (technology, location, equipment and raw material), human capital (training, experience, judgement, intelligence, relationships and insight) and organisational capital (structure, planning, controlling, coordination of systems, and internal relationships) that a firm uses to implement its strategies to achieve competitive advantage in the market (Barney, 1991). The use of resources for competitive advantage highlighted that accelerator programmes aimed to create successful startups by providing them with the required resources to enable this success.

Human resources related services provided by accelerators are the biggest resources provided through mentorship matched with startup, is supported by Yitshaki, and Drori, (2018) to share knowledge that opens up various opportunities to help gain competitive sustained advantage. This agrees with RadojevichKelley and Hoffman, (2012) on resources that accelerators provide. However Ireland, et al. (2003) looked at human capital, and markets that includes customers and networks. Financial capital as stated by Radojevich-Kelley and Hoffman, (2012) included funding to support the growth of startups. This was offered on a grant basis, ventures, equity, accelerator programme's networks and own resources (e.g. Grindstone through Knife Capital). Winston Smith et al. (2013) emphasise the surety of funding for accelerator beneficiaries. Adner \& Helfat, (2003), Ireland, et al., (2003) supported this when they focused on managing resources strategically.

Organisations' structural resources with the ecosystem which focus on leadership and government policy, culture (including success stories and societal norm), support services (including infrastructure and other services) as stated by Radojevich-Kelley and Hoffman (2012) however these were difficult especially those in ideation stage as these startups have not yet formed their own organisations. These can be linked to other notable physical resources include office space and co-working space as office infrastructure offered by accelerators such as LaunchLab and MLab. Administrative resources have also enhanced access and provide legal, accounting and financial services in putting systems and processes in place that will assist them to execute their strategy. These are valuable because improve efficiency and effectiveness, identify and exploit opportunities and neutralise threats in the external environment. Nonsubstitutable resources tend to possess attributes that provide companies with a competitive advantage (Barney, 1991). Finally the combination of the knowledge transferred from mentors and founders cannot be replicated thus bringing unique historical condition, that are ambiguous, socially complex, and imperfectly imitable (Barney, 1991). Thus stronger skill set means higher business performance (Lerner and Almor, 2002)

Human, financial, infrastructure as accelerators' internal capabilities (Koponen, 2012; Smith \& Stevens, 2010; Barney 1991) gets strengthened when combined with mentors (expert skills and knowledge of the sector) and needs of sector partners, competitors, buyers and suppliers. These create platforms that enable beneficiaries to create new value (Teece et al., 2010), and capitalise on accelerators' resources. SMMEs and entrepreneurs as beneficiaries are enabled to supplement and complement strategic alliances (Wassener \& Dussauge, 2011) in the accelerator process (at any stage of development). Whereas collaboration amongst SMMEs and entrepreneurs strengthen each other's strategic imperatives to enhance competitive (Yunus et al., 2010; Alt \& Zimmerman, 2014; Ostenwalder et al., 2005; Mahadevan, 2000, and Schweizer, 2005).

\section{Conclusions \& Recommendations}

It can be concluded that accelerator programmes assist startups to be sustainable into the future by offering necessary funding and mentorship. The growth of accelerator programmes seems to be driven by the recognition of a funding as well as a knowledge gap in the startup market to catalyse sustainable and successful startups that leads to job creation, economic growth and long-term sustainability for the startups. Successfully accelerator programmes meet the challenge of the knowledge and funding gap through increased support by public and private sector organisations of accelerator programmes. It is however essential for supportive policies to enhance private sector participation so as to provide the necessary funding. With more funds needed these can be specifically channelled to accelerator programmes that have the proven track record of accelerating startups to success.

\section{References}

1. Accelerate Cape Town, Grindstone Accelerator Programme. [Online] Available at: http://acceleratecapetown.co.za/wp/wpcontent/uploads/2017/03/Grindstone-Accelerator-@-Knife-Capital.pdf [Accessed 24 June 2018].

2. Alt, R., \& Zimmerman, H.-D. (2014). Editorial 24/4: Electronic markets and business models. Electron Markets, 24, $231-234$.

3. Alvarez, S. A., \& Busenitz, L. W. (2001). The entrepreneurship of Resource Based Theory. Journal of management, 27(6), 755-775.

4. Barney, J. (1991). Firm resources and sustained competitive advantage. Journal of management, 17(1), 99-120.

5. Baskarada, S. (2014). Qualitative case study guidelines. The Qualitative Report, 19(40), 1-25.

6. Baxter, P., \& Jack, S. (2008). Qualitative case study methodology: Study design and implementation for novice researchers. The qualitative report, 13(4), 544-559.

7. Bretherton, P., \& Chaston, I. (2005). Resource dependency and SME strategy: an empirical study. Journal of Small Business and Enterprise Development, 12(2), 274-289.

8. Brown, R., \& Mawson, S. (2016). Targeted support for high growth firms: Theoretical constraints, unintended consequences and future policy challenges. Environment and Planning C: Government and Policy, 34(5), 816-836.

9. Clarysse, B., \& Yusubova, A. (2014). Success factors of business accelerators. Technology Business Incubation Mechanisms and Sustainable Regional Development. Proceedings. Presented at the Technology Business Incubation Mechanisms and Sustainable Regional Development. 
10. Cohen, S. L. 2013. How to accelerate learning: Entrepreneurial ventures participating in accelerator programs. [online] Available at: https://cdr.lib.unc.edu/indexablecontent/uuid:3f1e2291-3eb5-4206-9441-9ee1aa03716d [Accessed 30 June 2018].

11. Cohen, S., \& Hochberg, Y. V. 2014. Accelerating startups: The seed accelerator phenomenon. [online] Available at: http://seedrankings.com/pdf/seedaccelerator-phenomenon.pdf [Accessed 27 July 2017].

12. Conner, K., \& Prahalad, C. (1996). A resource-based theory of the firm: Knowledge versus opportunism. Organisation Science, 7(5), 477-501.

13. Cremers, M., Driessen, J., Maenhout, P., \& Weinbaum, D. (2009). Does skin in the game matter? Director incentives and governance in the mutual fund industry. Journal of Financial and Quantitative Analysis, 44(6), 1345-1373.

14. De Vos, A. S., Delport, C. S. L., Fouché, C. B., \& Strydom, H. 2011. Research at grass roots: For the social science and human professions (4th Edition). Van Schaik Publishers.

15. Fahy, J., \& Smithee, A. 1999. Strategic Marketing and the Resource Based View of the Firm, Academy of Marketing Science Review (10).

16. Fehder, D., \& Hochberg, Y. 2018. Accelerators and the regional supply of venture capital investment. [online] Available at: http://yaelhochberg.com/assets/portfolio/FH.pdf [Accessed 30 June 2018].

17. Global Accelerator Learning Initiative, 2017. Global Accelerator Survey 2016. [online] Available at: https://www.galidata.org/accelerators/ [accessed 21 April 2018].

18. Grant, R. M. 1991. The Resource Based Theory of competitive advantage: implications for strategy formulation. Knowledge and strategy. Elsevier., pp. 323.

19. Gust, 2017. Global Accelerator Report. [online] Available at: http://gust.com/accelerator_reports/2016/global/ [accessed 21 April 2018].

20. Hallen, B. L., Bingham, C. B., \& Cohen, S. 2014. Do accelerators accelerate? A study of venture accelerators as a path to success? Academy of management proceedings. 14 (1) pp. 12955-12955.

21. Hamel, G. (2000). Leading the revolution. Boston: Harvard Business School Press.

22. Hitt, M. A., Xu, K., \& Carnes, C. M. (2016). Resource Based Theory in operations management research. Journal of operations management, $41,77-94$.

23. Hochberg, Y. V. (2016). Accelerating entrepreneurs and ecosystems: The seed accelerator model. Innovation Policy and the Economy, 16(1), $25-51$.

24. infoDev, 2018. About infoDev A World Bank Group Program to Promote Entrepreneurship \& Innovation [online] available at: http://www.infodev.org/about [Accessed 29 June 2018].

25. Ireland, R. D., Hitt, M. A., \& Sirmon, D. G. (2003). A model of strategic entrepreneurship: The construct and its dimensions. Journal of management, 29(6), 963-989.

26. Isenberg, D. 2014. What an Entrepreneurship Ecosystem Actually Is. [online] Available at: https://hbr.org/2014/05/what-an-entrepreneurial-ecosystemactually-is [Accessed on 2 October 2017.].

27. Knife, \& Capital, 2018. Grindstone Accelerator. [online] Available at: https://www.knifecap.com/grindstone [Accessed 30 June 2018].

28. Kraaijenbrink, J., Spender, J., \& Groen, A. J. (2010). The resource-based view: a review and assessment of its critiques. Journal of management, 36(1), 349-372.

29. Koponen, D. (2012). Conceptual framework for quality of life management: Social entrepreneurship perspective. Economics and Management, 17(4), 1372-1377.

30. Li, Y., \& Rama, M. (2015). Firm dynamics, productivity growth, and job creation in developing countries: The role of micro-and small enterprises. The World Bank Research Observer, 30(1), 3-38.

31. Lerner, M., \& Almor, T. (2002). Relationships among strategic capabilities nd the performance of women-owned small ventures. Journal of Small Business Management, 40(2), 09-125.

32. Levinsohn, D. S. 2015. No entrepreneur is an island: An exploration of social entrepreneurial learning in accelerators [online] Available at: http://www.divaportal.org/smash/get/diva2:813389/FULLTEXT01.pdf [Accessed 26 June 2018].

33. MahadevaN, B. (2000). Business models for Internet-based e-commerce: An anatomy. California Management Review, 42(4), pp55-69.

34. Makador, R. (2001). Toward a synthesis of the resource-based and dynamic-capability views of rent creation. Strategic Management Journal, 22, 387401.

35. Michalisin, M., Smith, R., \& Kline, D. (1997). In search of strategic assets. International Journal of Organisational Analysis, 5, $360-387$.

36. National Development Plan (NDP) National Planning Commission, 2011. Our future - make it work. National Development Plan 2030 Executive Summary. [online] Available at: http://www.gov.za/sites/www.gov.za/files/Executive\%20Summary-NDP\%202030\%20-\%200ur\%20future\%20-

\%20make\%20it\%20work.pdf [Accessed 23 July 2017].

37. Ormiston, J., \& Seymour, R. (2011). Understanding value creation in Social Entrepreneurship: The importance of aligning mission, strategy and impact measurement. Journal of Social Entrepreneurship, 2(2), 125-150.

38. Ostenwalder, A., Pigneur, Y., \& Tucci, C. L. (2005). Clarifying Business Models: Origins, Present, and Future of the Concept. Communications of Association for Information System, 15, 1-43.

39. Peteraf, M. A. (1993). The cornerstones of competitive advantage: A resource-based view. Strategic Management Journal, 14(3), $179-191$.

40. Pauwels, C., Clarysse, B., Wright, M., \& Van Hove, J. (2016). Understanding a new generation incubation model. The accelerator. Technovation, 50, $13-24$.

41. Radojevich-Kelley, N., \& Hoffman, D. L. (2012). Analysis of accelerator companies: An exploratory case study of their programs, processes, and early results. Small Business Institute Journal, 8(2), 54-70.

42. Strategic Capabilities of Ghanaian Female Business Owners and The Performance of Their Ventures 
Saffu, K., \& Manu, T. 2005 Strategic Capabilities of Ghanaian Female Business Owners and The Performance of Their Ventures.

43. Schumpeter, J. A. (1934). The Theory of Economic Development. Cambridge: Harvard University Press.

44. Schweizer, L. 2005. Concepts and Evolution of Business Models, France Journal of General Management, 31(2) Winter.

45. Smith, B. R., \& Stevens, C. E. (2010). Different types of social entrepreneurship: The role of geography and embeddedness on the measurement and scaling of social value. Entrepreneurship \& Regional Development. An International Journal, 22(6), 575-598.

46. Slide, \& Share, 2017. Sw7. The South African Tech Startup Community and Economy [Online] Available at: https://www.slideshare.net/KeithJones52/sw7the-south-african-tech-startup-community-and-economy [Accessed 10 June 2018].

47. Agency, S. E. D. 2016. The small, medium and micro Enterprise sector of South Africa [online] Available at: http://www.seda.org.za/Publications/Publications/The\%20Small,\%20Medium\%20and\%20Micro\%20Enterprise\%20Sector\%20of\%20South\%20Africa\%20C [Accessed 12 August 2017].

48. Southern African Venture Capital and Private Equity Association, 2017. Venture Capital Survey [online] Available at: http://savca.co.za/wpcontent/uploads/2017/09/VC-Survey-2017-Electronic.pdf [Accessed 13 June 2018].

49. South Africa's Enterprise and Supplier Development Landscape, 2018. Programme: Grindstone Accelerator [online] Available at: http://www.esdsa.com/grindstone-accelerator.html [Accessed 10 June 2018].

50. Spark International, 2018. Information Pack. [online] Available at: http://www.sparkinternational.org/\#changing-lives [Accessed 25 May 2018 ].

51. Spark International, 2018. Outcomes: How we measure the outcomes of our work to support entrepreneurs that change lives. [online] Available at: http://www.sparkinternational.org/\#changing-lives [Accessed 24 June 2018].

52. Connect, S. B. B. 2015. SW7 Acceleration Programme. [online] Available at: https://bizconnect.standardbank.co.za/events/sw7-accelerationprogramme.aspx [Accessed 24 June 2018]

53. Techstars, 2017. Mentoring at Techstars. [online] Available at: https://www.techstars.com/mentoringattechstars/ [Accessed 30 June 2018].

54. Teece, D. J. (2010). Business models, business strategy and innovation. Long Range Planning, 43, 172-194.

55. Ventureburn, 2013. Knife Capital launches new Accelerator for post-revenue startups [online] Available at: http://ventureburn.com/2013/05/knife-capitallaunches-new-accelerator-for-post-revenue-startups/ [Accessed 24 June 2018].

56. Ventureburn, 2014. Meet Sw7, the latest tech incubator to take no equity, let you keep your day job [online] Available at: http://ventureburn.com/2014/06/meet-sw7-the-latest-tech-incubator-to-take-no-equity-let-you-keep-your-day-job/ [Accessed 10 June 2018].

57. Ventureburn, 2015. These are Grindstone's 13 tech startups for 2015 [online] Available at: http://ventureburn.com/2015/01/grindstones-13-tech-startups2015/ [Accessed 24 June 2018].

58. Ventureburn, 2016. Sw7 Tech Innovation Hub to open in JHB [online] Available at: http://ventureburn.com/2016/10/sw7-innovation-hub/ [Accessed 10 June 2018].

59. Ventureburn, 2016. Applications to the Spark* South Africa 2018 Accelerator Programme now open [online] Available at: http://ventureburn.com/2018/01/spark/ [Accessed 10 June 2018].

60. Ventureburn, 2017. 2017 Ventureburn Tech Startup Survey presentation [online] Available at: http://ventureburn.com/2017/11/ventureburn-startup-surveypresentation/ [Accessed 30 June 2018].

61. Ventureburn, 2017. Unpacking South Africa's tech startup and scaleup investor landscape, [online] available at: http://ventureburn.com/2017/05/unpacking-tech-startup-scaleup-investor-landscape-sa/ [Accessed 15 August 2017].

62. Winston Smith, S., Hannigan, T., \& Gasiorowski, L. L. 2013. Accelerators and Crowd-Funding: Complementarity, Competition, or Convergence in the Earliest Stages of Financing New Ventures?. Abstract only. [online] Available: https://papers.ssrn.com/sol3/papers.cfm?abstract_id=2298875 [accessed 30 June 2018].

63. Combinator, Y. 2018. About Y Combinator [online] Available at: http://www.ycombinator.com/about/ [Accessed 15 April 2018]

64. Yin, R. K. 2009. Case study research and applications: Design and methods. Sage publications.

65. Yitshaki, R., \& Drori, I. 2018. 4. Understanding mentorship. Accelerators: Successful Venture Creation and Growth. [online] Available at: https://events.insead.edu/doriot-entrepreneurship-conference/documents/Understanding-mentorship-processes-within-accelerators.pdf [Accessed 30 June 2018].

66. Yunus, M., Moingeon, B., \& Lehmann-Ortega, L. (2010). Building Social Business Models: Lessons from the Grameen Experience. Long Range Planning, $43,308-325$.

\section{Figures}




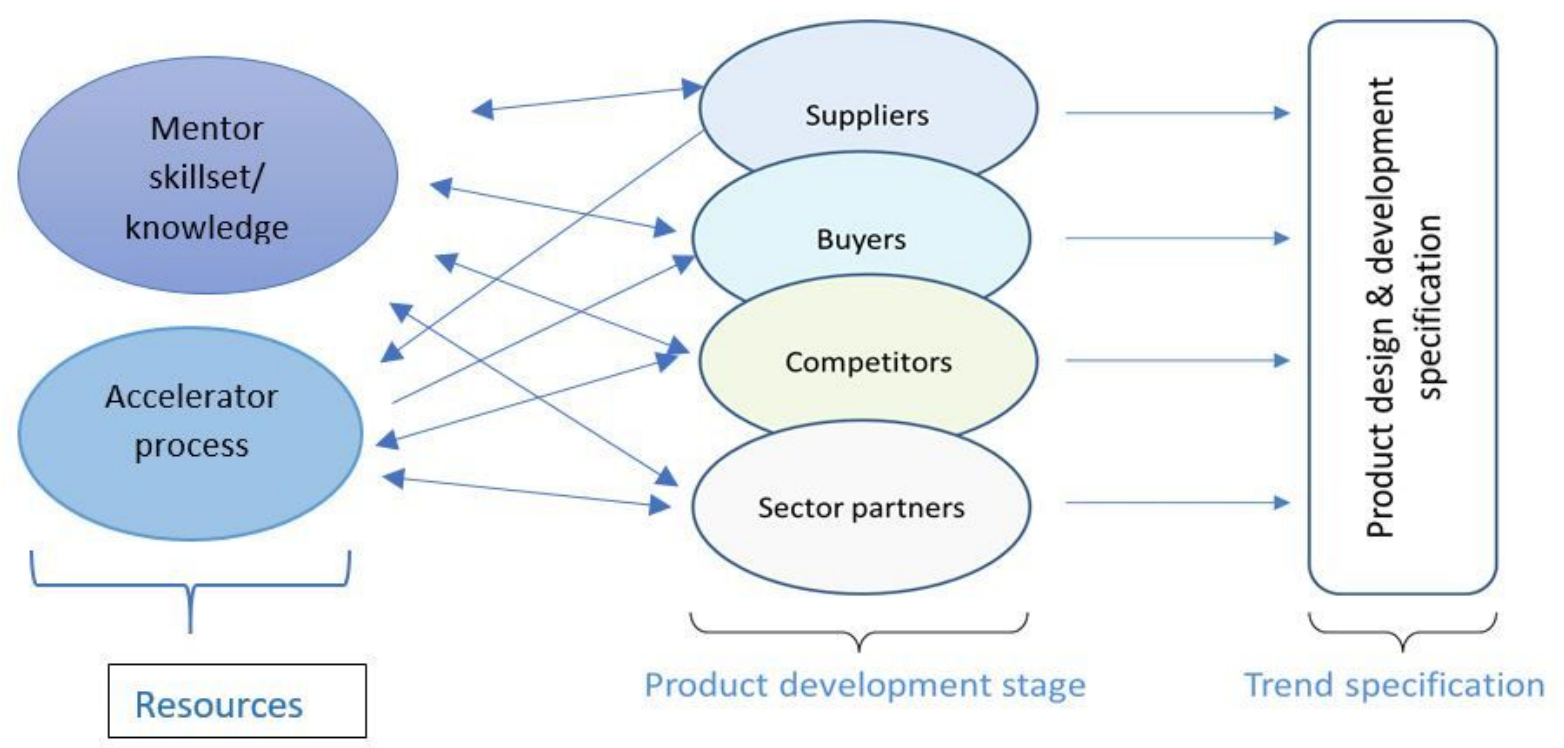

Figure 1

Strengthened Internal Capabilities 